OPEN ACCESS

Edited by:

Victoria Team,

Monash University, Australia

Reviewed by:

Xiaoman Zhao,

Renmin University of China, China

Youllee Kim,

University of Denver, United States

Julie Homchick Crowe,

Seattle University, United States

Jennifer K. Ptacek

University of Dayton, United States

${ }^{*}$ Correspondence:

Lorella Viola

lorella.viola@uni.lu

orcid.org/0000-0001-9994-0841

https://lorellaviola.me.uk

Specialty section

This article was submitted to Health Communication,

a section of the journal

Frontiers in Communication

Received: 12 August 2021

Accepted: 27 January 2022

Published: 22 February 2022

Citation:

Viola L (2022) "Italy, for Example, Is

Just Incredibly Stupid Now".

European Crisis Narrations in Relation to Italy's Response to COVID-19.

Front. Commun. 7:757847 doi: $10.3389 /$ fcomm.2022.757847

\section{"Italy, for Example, Is Just Incredibly Stupid Now". European Crisis Narrations in Relation to Italy's Response to COVID-19}

\author{
Lorella Viola* \\ Luxembourg Centre for Contemporary and Digital History $\left(\mathrm{C}^{2} \mathrm{DH}\right)$, University of Luxembourg, Esch-sur-Alzette, Luxembourg
}

Crisis narratives shape public understanding and, consequently, the response to the crisis itself. In the context of the COVID-19 pandemic, when in February 2020 Italy was experiencing more cases than any other country, the Italian response to the crisis originated debates over how to best respond to the outbreak. Informed by Critical Discourse Analysis theory and using narrative networks as a framework for the critical analysis of narratives, this study analyzes the discourse strategies employed by experts, politicians and other social actors from Spain, France, the Netherlands, and the UK when presenting their domestic measures in relation to Italy's response to coronavirus. The analysis shows that the narratives attached to nation-specific decisions were highly culturalized and connected to country-specific shared experiences, such as a sense of national exceptionalism built in opposition with the denigration of Italy as the Otheridentity. Attribution of blame and blameworthiness was also found to be a common pattern across countries according to which Italians were framed as wrongdoers but also as deserving blame. The article also presents a comprehensive "timeline of narratives" which opens avenues for a critical reflection on the impact such narratives may have had on the understanding of the crisis, including the creation of a negative climate of division and inappropriate crisis responses.

Keywords: crisis communication, COVID-19, narrative analysis, Italy, Critical Discourse Analysis, narrative network analysis

\section{INTRODUCTION}

The COVID-19 virus was not the first time that the causative agent behind SARS-a novel kind of coronavirus-was identified in human populations; the SARS epidemic of 2002-2003 had preceded it (Drosten et al., 2003; Ksiazek et al., 2003). Much of the same questions about the SARS-associated coronavirus (SARS-CoV) that had puzzled scientists 17 years before reemerged. For instance, how to distinguish the diagnosis from a seasonal flu, what the mortality rate and the incubation period were, what the best way to treat patients was, and how medical personnel and the most vulnerable people in society could be best protected (Fidler, 2004, p. 5). Although national and international public health officials and practitioners thought that they were confronted with what at first seemed to be a déjà $v u$ scenario, the speed and volume of the coronavirus contagion rate eventually made it clear that COVID-19 was a much more severe infectious disease than SARS. In 2004, 
SARS had been called "the first pandemic of the 21st century" (LeDuc and Barry, 2004) as it had spread across 29 countries, infected 8,098 people over the course of 8 months, and killed 774 (WHO); just a month after the first COVID-19 confirmed case, the total global case count had surpassed that of SARS. Although it seemed to have a lower infection fatality rate, the novel coronavirus was spreading much faster. Therefore, without any effective diagnosis, therapeutic modalities, enough intensive care facilities, prevention protocols, or vaccine technologies, the most urgent challenge of all was how to contain the spread of a new virus transmitted by respiratory means in the context of the highly globalized world society of the twenty-first century.

The combination of fear and confusion that COVID-19 was bringing represented a global threat to individuals and societies around the world, while to countries and industries, it was painting the terrifying picture of a global economic collapse. Such major disruption of established paradigms therefore required urgent intervention and the rapid devise of effective strategies, including communicative. Indeed, when uncertainty and confusion are at their most acute peak, the way a crisis is communicated becomes a central component of the crisis management itself (Reynolds et al., 2005; Coombs, 2007; Seeger and Sellnow, 2016; Patrona, 2018). According to Seeger and Sellnow (2016), as a highly uncertain and deeply disruptive situation, crisis creates "a narrative space, a communication vacuum, or a meaning deficit" (Seeger and Sellnow, 2016, p. 5) which needs to be filled with stories that can help make sense of it. But in the context of the COVID-19 health crisis, particularly the early stages of the outbreak were characterized by great discrepancy in national and international positions of how to best respond to the emergency; such discrepancy necessarily created competing narratives and counter-narratives of the COVID-19 crisis, persuasive stories that could legitimize and explain to the public the country differences in crisismanagement approaches but which, at the same time, created a complexity of voices that added even more confusion to an already uncertain, historically unprecedented situation. For example, in late February 2020 when Italy was the country with the highest number of confirmed cases of COVID-19, the Italian crisis response soon became the center of European governments' attention and originated debates over how to best respond to the epidemic. Thus, in addition to being a health, economic, security, political, and social issue, the COVID-19 health crisis became also a discourse event in which many different versions of the situation constructed competing discourse realities of both the crisis and the measures to tackle it. This study analyzes the narratives constructed and used to communicate the crisis and the measures to contain it in the very first moments of the emergency. Specifically, the analysis compares discourse strategies and narratives employed by experts, politicians and other social actors from a range of European countries-Spain, France, the Netherlands, and the UK-when presenting their domestic management measures in comparison to Italy's response to the health crisis. The study rests on the foundation that examining the narratives used by key players to express blame and responsibility, to legitimize their response strategy, and to mobilize support clarifies how a crisis is understood at national and international levels.

The study uses Critical Discourse Analysis theory (CDAFairclough and Wodak, 1997) as the applied theory for the analysis of the COVID-19 crisis narratives. Crises are shaped by those in positions of power, hence crisis narratives are also attempts at maintaining power. CDA focusses on how power is manifested and enacted through language and it looks at the historical, political and ideological mechanisms at work within a discourse event; it therefore helps uncover the latent assumptions and ideologies embedded in and circulated through stories and consequently the larger culture that creates the narratives and generates the wider discourse attached to them (Stokes, 2021). Here crisis is conceptualized through the lens of discourse and therefore its communication is understood as a form of social practice (Fairclough and Wodak, 1997, p. 258) rather than a purely linguistic phenomenon.

As a distinctive feature, the study integrates CDA with the analytical method of narrative networks (Bearman and Stovel, 2000; Gimenez, 2010). Seeger and Sellnow (2016) argue that crisis narratives cluster around a core set of meanings which ensue a network of narratives; this network of narratives impact on culture, beliefs, norms, policies, and institutions thus ultimately shaping the crisis. Narrative networks looks at narratives as embedded in a wider network of meanings between the local and social functions that they represent; it therefore perfectly complements CDA theory as it best captures when local narratives are networked with other narratives, in both local and global contexts (Gimenez, 2010). The tension between these two contexts make narratives compete in the public forum for power, credibility, and acceptance; understanding the role of these narratives sheds light on how crises are understood and it helps anticipate the post-crisis social changes (Seeger and Sellnow, 2016, p. 14). In this way, this study also presents a comprehensive "timeline of narratives" which opens up avenues for a critical reflection on the impact these may have had on the general understanding of the crisis, including the creation of a negative climate of criticism and division and inappropriate crisis responses.

A second distinctive feature of this study is that it adopts a cross-cultural perspective. As recently pointed out by Bajaj et al. (2021), there are to date few studies that have analyzed transcultural crises through a cross-cultural and intercultural lens. Yet narratives are influenced by the cultural, social, and ideological views of both the narrator and the message's recipients and therefore culture is a key factor to crisis management and response. Thus, the cross-cultural approach in this study has wider relevance for practitioners as well as health communication researchers as the findings offer important knowledge about the cultural dimension of global health crisis communication management.

\section{COVID-19 AS A DISCOURSE EVENT}

While to this date it is unclear who the so-called patient zero was, according to the WHO, the first ever case of COVID-19 might have been in China on 8 December 2019 


\section{The Coronavirus in Europe}

Confirmed cases of the COVID-19 coronavirus in Europe*

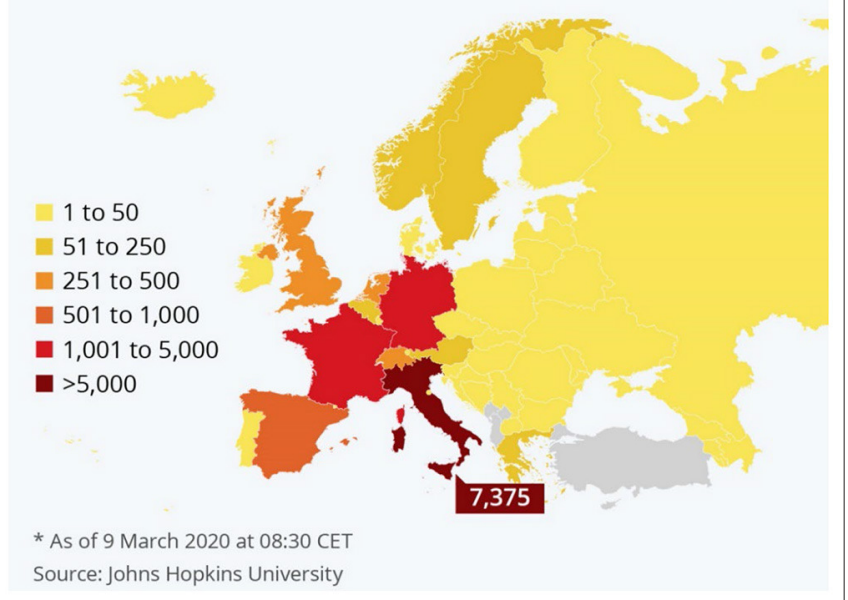

FIGURE 1 | COVID-19 confirmed cases in Europe as of 9 March 2020. Chart available at https://www.statista.com/chart/20964/covid-19-cases-europemap/.

(WHO|Novel Coronavirus-China, 2020). In Europe, the first reported case was found in Bordeaux, France on 24 January 2020 (Reuters, 2020) with two more cases reported in Paris later that day. Two other cases were reported in Bavaria, Germany on 27 January 2020 (Berliner Morgenpost, 2020) and in Finland, on 28 January (Yle Uutiset, 2020). On 31 January, the first two cases were confirmed in Rome (Corriere della Sera, 2020). Although scattered cases had since appeared all over Europe, it was in the Italian region of Lombardy that the first cluster of 16 cases was detected on 21 February (Amante and Anzolin, 2020). On 22 February, additional 60 cases were confirmed and Italy reported the first deaths (Corriere della Sera, 2020).

As of late February, with confirmed cases in all regions, Italy had been hit harder than anywhere else in Europe. Prime Minister at the time Giuseppe Conte declared a state of emergency, placed under quarantine the eleven municipalities that had been identified as the centers of the two main clusters, later expanded the quarantine to all of Lombardy and 14 other northern provinces, and finally to the entire country on 8 March 2020 , placing more than 60 million people in quarantine (BBC News, 2020). The Italian lockdown decree prohibited all nonessential shops and services, businesses and industries and all public and private gatherings of any number of people; it also restricted movement, including movement across regions as well as within the same region (Safi et al., 2020). Figure 1 shows the distribution of cases in Europe as of 9 March 2020 and evidences that the highest concentration of cases was reported in Italy.

On 30 January 2020, WHO Director-General, Dr. Tedros Adhanom Ghebreyesus, had declared that the novel coronavirus outbreak was "a public health emergency of international concern" (WHO, 2020a). At that moment, there were 98 cases and no deaths in 18 countries outside China. On 11 March
2020 , with more than 118,000 cases reported in 114 countries and 4,291 deaths, WHO announced that the outbreak could be characterized as a pandemic (WHO, 2020b); 2 days later, the organization stated that Europe was "the active center of the pandemic" (WHO, 13 March 2020). On 19 March 2020, Italy had surpassed China for number of deaths, while by 26 March, with the highest number of confirmed cases in the world, the United States had overtaken both China and Italy. Since then, a steady growing number of cases has been recorded globally, albeit with differences across countries. Figure 2 shows the aggregated number of confirmed cases of COVID-19 in the world from 22 January to 18 July 2020.

The overview given here illustrates the very rapid escalation of events that characterized the COVID-19 pandemic, particularly in the first months of 2020 and it highlights two important facts relevant to this study: (1) governments and public health officials found themselves confronted with an unprecedented situation that required immediate action and (2) to be accepted by the nation, such actions-no matter how extreme-needed to be presented to the public as the best possible solutions. These stories created a complex and often conflicting set of discourse realities; the plethora of storylines primarily concerned the origin, prevention, diagnosis, and treatment of the disease. Even authoritative figures and institutions were giving insufficient, often contradictory information and advice that were later reversed. Moreover, deliberate misinformation practices and conspiracy theories spread particularly but not exclusively through social media and were propagated by private citizens, celebrities, politicians and other prominent figures (Douglas, 2021; Stein et al., 2021; Pummerer et al., 2022). The enormous media distribution of false claims eventually led the WHO to declare that together with the pandemic, the world was facing an "infodemic" of incorrect information about the virus, which was posing additional risks to global health (United Nations, 2020).

Research has pointed out how media are active coproducers of discourses, hence discourses produced via media not only shape meaning but determine reality too (Jäger, 2001, p. 36; Wodak and Meyer, 2001). Works in a large variety of fields such as media studies (Bryant et al., 2002; Entman, 2003), discourse studies (van Dijk, 1985; Baker et al., 2013), political communication studies (Arceneaux and Johnson, 2013; Boydstun, 2013; Atkinson, 2017), to name but a few have consistently demonstrated that, as public opinion is largely informed by mass media, media discourse gradually alters the public perception of reality, for instance by creating a sense of urgency in a crisis, by using "us" vs. "them" narratives to negatively frame specific social categories, or by emphasizing policy priorities and government choices, thus de facto playing an agenda-setting role. Indeed, as crises are in general newsworthy, the media discourse attached to them greatly influences public opinions and alignments (Patrona, 2006, 2012). Therefore, while the concrete facts of a crisis may be objectively undeniable, the narratives used to explain them may shape the way they are interpreted and determine whether they will be accepted or contested. At the same time, they may influence the way other producers will construct their own narratives thus ultimately impacting on the general understanding of the crisis. Understanding discourse as social 


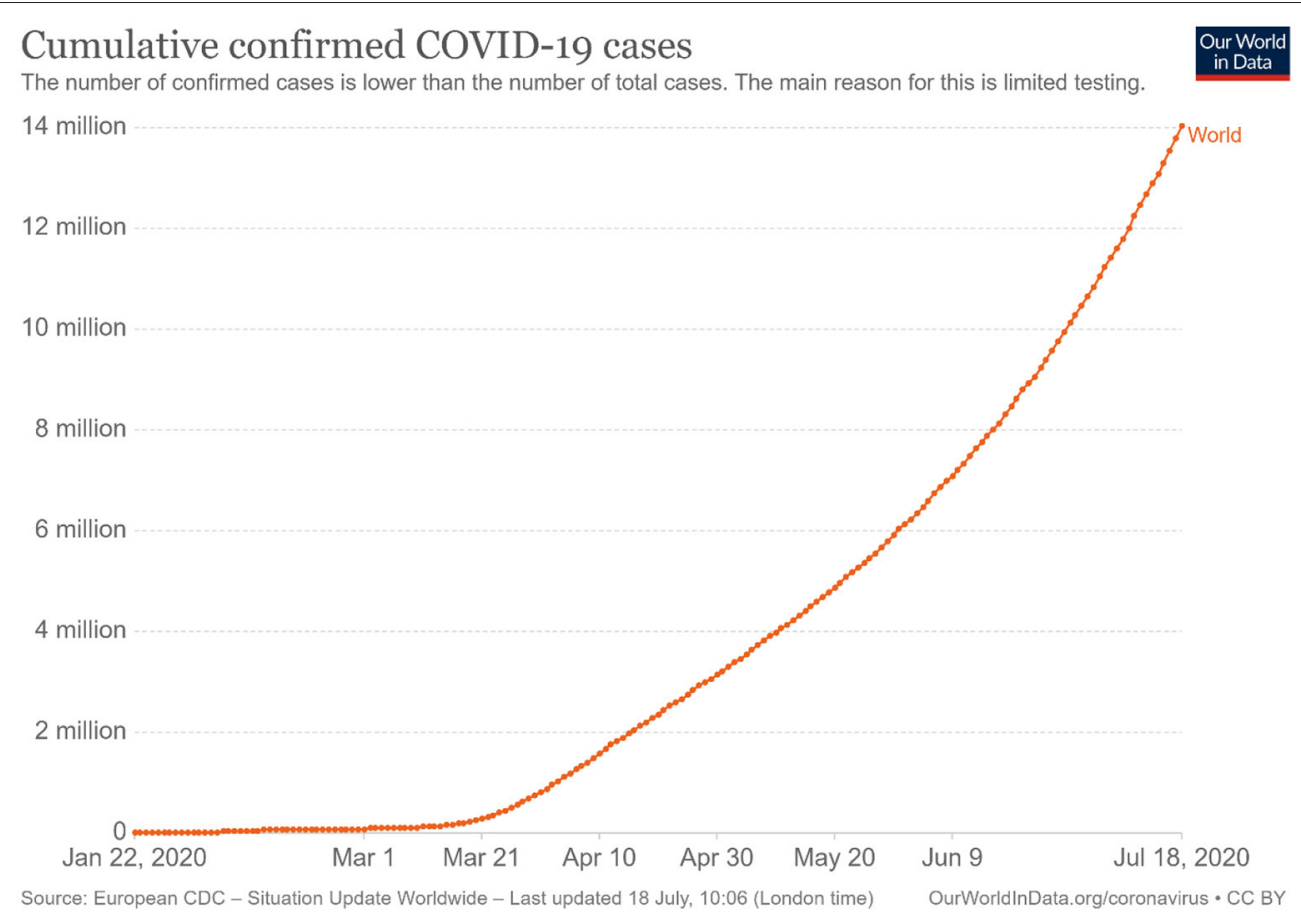

FIGURE 2 | Confirmed cases of COVID-19 globally as per 18 July 2020.

rather than purely linguistic crucially entails that meaning is continually negotiated through interaction. It also means that it is performance-oriented (Potter and Wetherell, 1987; Edwards, 1997; Potter et al., 2016) in the sense that it constructs realities (i.e., a discourse event) in which blame can be attributed, facts can be accounted for, and specific actors can be presented or obscured (Fairclough and Wodak, 1997, p. 258), for instance to justify the governments' unpreparedness in managing a crisis. Thus, from the perspective of agency, they can conceal or point to specific actors and allow for a strategic attribution of blame (e.g., Wodak and Angouri, 2014); they can legitimize specific management decisions or serve to justify an incompetent response; or they can explain the resolution strategies to the involved actors in order to mobilize the necessary support. The integration of CDA with narrative networks and the crosscultural perspective taken in this study examine narratives not as isolated discourse events but as part of a wider network of discourse realizations in which narratives are produced, shared and reproduced and it offers rich insights into the many factors at play determining the understanding of the crisis and the governments' response to it. Significantly, the approach identifies potential patterns and common themes in the narratives across countries which also contribute theoretical insights to research on health communication.

\section{METHODOLOGY, DATA COLLECTION AND SOURCES}

In the very early stages of the COVID-19 pandemic, the high uncertainty about how to best respond to the crisis combined with governments' generalized unpreparedness created a discourse void that needed to be filled with plausible stories. As the country with the highest number of recorded cases and deaths, Italy soon came under close scrutiny from other European countries and much of the discussion about the health crisis revolved around the Italian response to it. Following Seeger and Sellnow (2016), the main hypothesis of this study is that these crisis narratives shared recurring themes and characteristics such that specific discourse strategies can be identified across nations. Guided by CDA theory, the analysis focusses on how narratives of the health crisis were constructed with specific reference to: (1) the attribution of blame and type of object blamed; (2) minimizing strategies; (3) references to country-specific shared experiences; (4) use of familiar images (especially cultural); (5) explicitness and implicitness of language used; and (6) specific contextual factors such as the time of the message production and infection's figures. The intention is to understand how different actors in the analyzed four countries defined the terms to legitimize the domestic response to the pandemic in tension with the Italian response. The overarching aim is to explore if and how these positionings varied cross-culturally and whether the framing of the disease and crisis changed accordingly. As such, the study applies an a priori thematic saturation model (Saunders et al., 2018), whereby saturation "may refer to the extent to which pre-determined codes or themes are adequately represented in the data." Data has therefore been collected so as to exemplify theory-as opposed to develop theory-at the level of the pre-defined conceptual categories outlined above. 


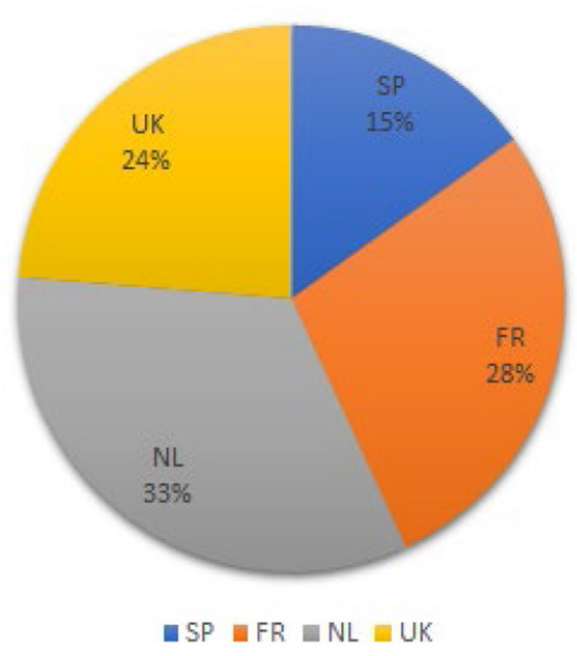

FIGURE 3 | Distribution of sources in the data-set.

The data sampling focused therefore on selecting material that could be considered representative of the established categories in each nation when discussing specifically the adopted domestic measures in relation to Italy's response to coronavirus. Efforts have been made toward choosing examples that could also be considered as emblematic - at least to an extent-of each country's predominant narrative, for example national media were preferred over local and regional media in the respective countries and editorial commentaries, experts' interviews and official statements were preferred over statements from the general public. However, due to the relatively limited number of excerpts analyzed, the material presented here should not be understood as fully illustrative of each country's main narrative, rather as part of the wider public discourse that rapidly unfolded in the first stages of the pandemic. However, as these narratives were produced by official spokespersons, experts and other prominent public voices and shared on national media, it can nevertheless be assumed that they did contribute to how the pandemic was being understood and internalized within each country and across countries.

The material for the analysis has been collected from the Europresse database, ${ }^{1}$ an aggregator of European media news outlets that includes printed press, television, radio, web press, blogs, social media, newsfeeds, and media reports from a variety of mainstream media outlets for a total of 8,044 media sources. The platform interface allows for granular searches through keywords and advanced filters such as language(s) of preference, type of media, media coverage (i.e., local, regional, national, international, continental), country's origin, media periodicity, and timeframe of publication. To allow for the same searches to be performed across languages, the following non-language specific keywords were used for the queries: COVID-19 OR

${ }^{1}$ http://www.europresse.com coronavirus AND Ital ${ }^{* 2}$; the search was restricted to headlines containing the keywords' parameters and by selecting only European media outlets other than Italy. The timeframe of relevance was set to the first 2 weeks of March 2020 as this is when Italy became the first country experiencing the peak of the crisis. Finally, to limit the sample to a manageable size and to allow for CDA and narrative network analysis to be performed, Spanish, English, French, and Dutch were chosen as the languages of preference ${ }^{3}$. The search returned 1,702 media items evenly distributed across the four countries as shown in Figure 3, thus making the data-set a balanced resource.

This is fundamentally a focus study; however, using the concordances software AntConc 3.5.8 (Anthony, 2019), preliminary observations were conducted; this step helped both validate the suitability of the collected material and the identification of relevant examples destined to the subsequent qualitative analysis. The search was conducted by using the AntConc's KWIC (KeyWord In Context) feature which allows to observe how words and phrases are commonly used in a corpus of texts in relation to specific words. The used keywords were: Ital ${ }^{*}$, COVID-19, pandemic, coronavirus, British, Français, Español ${ }^{*}$, Nederlander*. The results contributed useful material to map how Italy and the Italian response were linguistically represented in the media in tension with the domestic strategy. Finally, a close reading of these results focused on further selecting material containing statements by officially or institutionally entitled public voices such as doctors, politicians, and official spokespersons. Further examples have been retrieved from sources quoted or referred to in the sample; these excerpts are provided in Table $\mathbf{1}$ in the Discussion Section. Moreover, for the reconstruction of the events and figures of infections, tests and deaths, the data were taken from reports by the World Health Organization (WHO), John Hopkins University, and the European Centre for Disease Prevention and Control (ECDC).

The qualitative analysis proceeds in three steps; firstly, guided by narrative networks analysis, it places narratives in a structure of time sequence. The narratives are accordingly analyzed in chronological order and examined in relation to the concurrent events in Italy and in the country where each given discourse was produced. The problematization of time and events as integral part of the narratives' interpretation overcomes at least partially the potential risk in biases always present in qualitative analyses. Secondly, guided by CDA theory, the narratives of the health crisis are analyzed with specific reference to the six categories outlined above.

Thirdly, with specific reference to (6) (i.e., specific contextual factors such as the time of the message production and infection's figures), the analysis investigates potential patterns between the time when the discourse was produced, the use of the identified narratives and communicative strategies and potential escalations over time. The aim is to create a "timeline

\footnotetext{
${ }^{2}$ The asterisk is a commonly used wildcard symbol that broadens a search by finding words that start with the same letters and end with all possible combinations (e.g., Italy, Italian, Italiana, Italienne, Italië).

${ }^{3}$ The language selection was motivated by the author's language proficiency.
} 
Number of RT-PCR tests conducted in Europe in week 9 of 2020

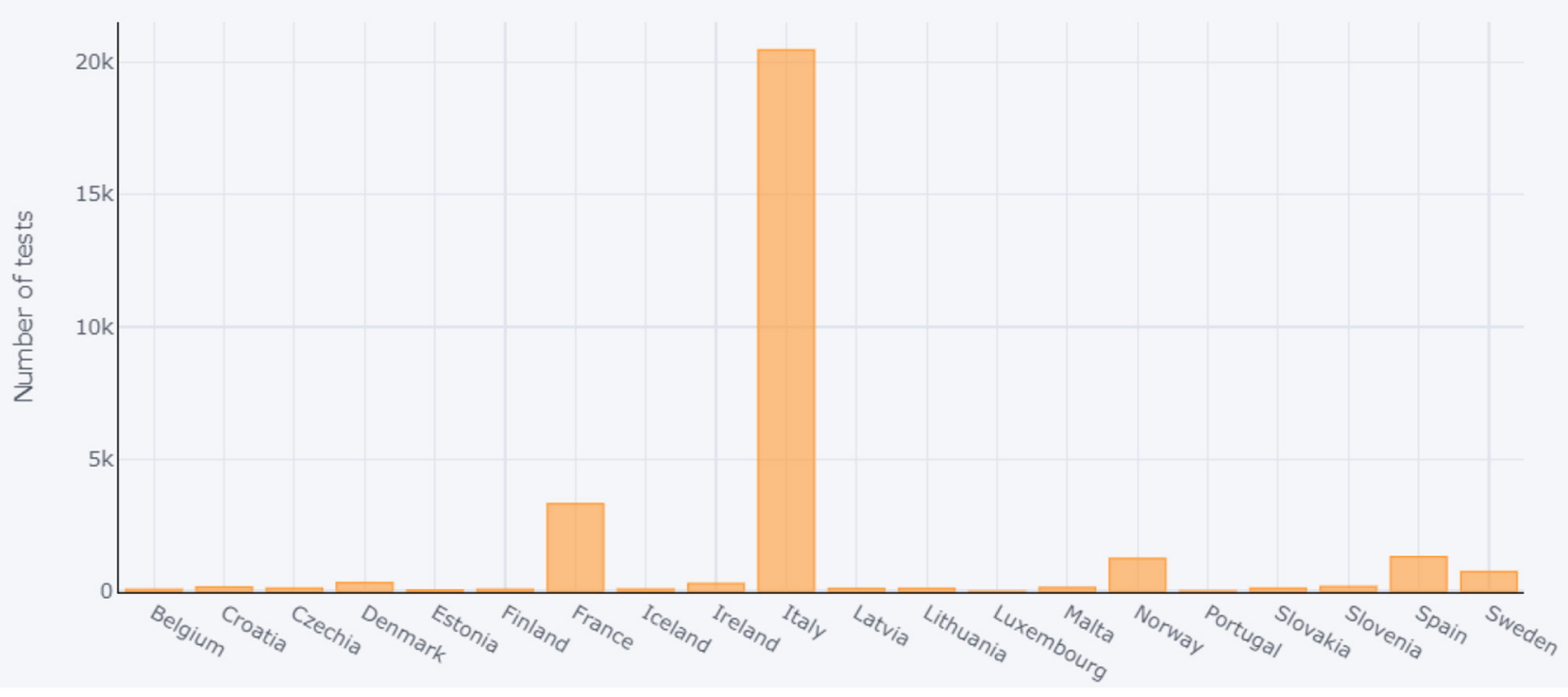

FIGURE 4 | Number of COVID-19 tests carried out in week 9 in Europe. Source: European Centre for Disease Prevention and Control (ECDC).

of narratives" in which narratives are triangulated both with events in the respective countries and the time of the analyzed statements. The final goal is to obtain a holistic, cross-cultural representation of crisis communication strategies in the analyzed European narratives and to open up avenues for a critical reflection on emerging common themes and the impact they may have had on the general understanding of the crisis, including the creation of a negative climate of criticism and division, for instance by becoming increasingly aggressive, and inappropriate crisis responses.

\section{ANALYSIS AND RESULTS}

This section applies CDA and narrative network analysis to several official or institutional statements from the four countries. The selection of the excerpts followed a chronological order so as to place the narratives within the context of each country's situation at the time when the corresponding analyzed speech event occurred; this approach helps identify potential relations across events, given reasons and causes. A discussion and synthesization of the findings are provided at the end.

\section{Spain, 2 March 2020}

As of 2 March 2020, Italy was counting 1,128 active cases (European Centre for Disease Prevention and Control-ECDC), 34 deaths and an average of 500 new daily infections. This was by then the highest number of reported cases in Europe; at the same time, however, since the outbreak, the country had carried out significantly more tests than any other country in Europe (Figure 4). Just as an example, in the first week of March, Italy had carried out 20,457 tests while France-the second European country for number of tests-had conducted 3,318 tests.

In the same week, Spain had registered 80 cases out of 1,318 tests. The so-called test positivity rate, that is the fraction of positive tests calculated from dividing the number of positive tests by the total number of tests, was 5.127829105 for Italy and 6.069802731 for Spain. This measure essentially indicates whether a country is carrying out enough tests: a higher rate suggests that there may be many more undetected cases. According to $\mathrm{WHO}$, the test positivity rate from a comprehensive testing program should be at or below $5 \%$ for at least 14 days (WHO, 2020c). Based on such guidelines, Italy appeared to not only conduct enough tests, but in comparison with Spain, it was also likely to have fewer undetected cases.

Nevertheless, the director of the Centre for Health Emergencies Coordination of the Spanish Ministry of Health (Centro de Coordinación de Alertas y Emergencias Sanitarias del Ministerio de Sanidad), Fernando Simón, on 1 March 2020, claimed that Italy had shown lack of coordination and that their management crisis measures had been "contradictory" (El Mundo, 2020). At that moment in time, Italy had enforced a series of emergency decrees which included crisis management measures such as the suspension of all sporting events in the regions of Lombardy and Veneto. Such containment measures were described by Simón as "strange" (extraño) particularly regarding the fact that Italian citizens were still allowed to leave Italy to attend sport events in other countries. Antoni Trilla, head of the Preventive Medicine and Epidemiology service (servicio de Medicina Preventiva y Epidemiología) at Hospital Clínic de Barcelona, echoed Simón's thoughts: 
(1) "Sobre todo al principio, Italia adoptó medidas controvertidas, ${ }^{4}$ como la decisión de tomar la temperatura a los viajeros que llegaban al país y, sin embargo, no a los que salían cuando ya había un foco de contagion."

(2) "Especially at the beginning, Italy adopted controversial measures, such as the decision to take the temperature to travelers arriving in the country but not to those who left when there was already a source of contagion ${ }^{5 "}$.

A normative stance about the importance of coordination is taken:

(3) "En una situación de crisis como la actual es necesaria una gestión coordinada que siga unos mismos protocolos y lleve a cabo medidas armonizadas a todos los niveles."

(4) "In a crisis situation such as the current one, it is necessary to have a coordinated response which follows the same protocols and carries out harmonized measures at all levels."

After criticizing the controversial measures taken by the Italian government, Simón claimed that $90 \%$ of the registered cases in Spain were in fact coming from Italy:

(5) "Vamos a basar nuestras decisiones en la evidencia de la circulación del virus de nuestro país. Ahora mismo sabemos que el $\mathbf{9 0 \%}$ de los casos en España provienen de Italia."

(6) "We will base our decisions on the evidence of the virus circulation in our country. We now know that $\mathbf{9 0 \%}$ of the cases in Spain come from Italy."

By framing the narrative as "empirical" ("evidence," "we now know”), Simón's statement conveys absolute certainty and therefore trustworthiness. It should however be noted that his use of figures (" $90 \%$ of the cases") is not supported by official sources but it is nonetheless linearly constructed in direct opposition with the "strange" and "uncoordinated" measures adopted in Italy. The oversimplified narrative creates a perception of reality which blames Italy for causing 90\% of infections in Spain and Spain is cleared from responsibility. The frame is further strengthened by the following statements in which both experts agree that the Spanish health system was responding very well, especially in terms of coordination:

(7) "Creo que España, en ese sentido, lo está haciendo muy bien" (Antoni Trilla)

(8) "I think Spain, in this sense, it's doing this really well"

(9) "Yo creo que tenemos unos profesionales asistenciales, unos médicos asistenciales y un servicio médicos buenos" (Fernando Simón)

(10) "I think that we have good professional assistants, professional doctors and a good health system"

On the whole, the narrative adopted by what the public may perceive as the two Spanish leading experts of coronavirus (for instance, the journalist from El Objetivo introduces Fernando Simón as "una de las personas que más sabe de este tema

${ }^{4}$ Unless otherwise specified, bold in the quotations is always added by the author.

${ }^{5}$ In this article, unless otherwise specified, all translations are by the author. en España") is built around criticism of the handling of the pandemic by the Italian government. However, the use of the image of Italians as being disorganized and uncoordinated seems to circulate a latent narrative: rather than being a mere analysis of a crisis management style, the Italian government is in fact scrutinized for having directly caused the spreading of the virus in Spain. This narrative is built according to a linear logic: if Italy had not failed to impose effective and more organized measures, Spain would only have $10 \%$ of infections. In such linear plot, oversimplified events allow narrators to disclaim responsibility for the negative outcome while placing the blame onto the other side.

\section{France, 9 March 2020}

By the third week of March 2020, the situation in Europe had changed dramatically. The number of reported infections was close to surpass those in China; cases were doubling over periods of 3-4 days on average and every 2 days in countries such as Italy, Spain, Austria and Germany (Roser et al., 2020). Different measures were being taken across the continent: Austria had prohibited major events, Spain and Denmark had prevented flights to and from risk areas, schools had been closed in Greece and the Czech Republic. It was Italy, however, that on 9 March, took the most drastic measure of all: with 1,492 new cases and a total of 366 deaths, the Italian Prime Minister Giuseppe Conte extended the quarantine lockdown to all of Italy, forbidding travels and public gatherings. Two days later, on 11 March 2020, the government issued the so called \#IoRestoACasa (\#IStayHome) decree which imposed further measures such as the suspension of all non-essential activities (Ratto Trabucco, 2020).

On the same day, France counted 1,126 total infections, of which 410 new, 19 total deaths and 9 new deaths. Minister of Solidarity and Health Olivier Véran was asked to comment on the Italian lockdown:

(11) "L'Italie fait face à une très grande détresse de son système hospitalier. L'Italie n'a pas le même système hospitalier que nous à la base. [...] Ils prennent donc une décision dans l'urgence, et qui est une décision qui leur appartient."

(12) "Italy is now experiencing a severely stressed hospital system. Italy does not have the same hospital system as us to begin with. [...] They are therefore taking a decision under pressure, and this is their decision" (BFM TV, 2020).

The adopted discourse strategy oversimplifies complex problems, selectively obfuscates agency while responsibility for failures is overtly attributed ("its hospital system") (Patrona, 2006, p. 2). On the whole, the crisis is presented as an "us" vs. "them" situation, in which the latter is blamed. Although Italy's hospital system is "severely stressed," the narrative does not frame the country as a victim, rather as being blameworthy (Wodak and Angouri, 2014, p. 418). This process of attributing blame necessarily has to involve "explanations, justifications and argumentation, as well as shared values which are referred to" (Wodak and Angouri, 2014). Here it is legitimized by the masked reference to an

\footnotetext{
6"One of the figures who knows more about this topic in Spain" (Guzmán, 2020).
} 
inefficient heath care system, not as efficient as the French one ("to begin with"), which forced Italians to make a rush decision in extreme circumstances. The implicit side of the argument appears to be that Italy is the ultimate cause of its own crisis. As France benefits from a more efficient health care system, the decision of ordering a lockdown does not apply ("it's their decision"). Prime Minister at the time Édouard Philippe also commented on the effectiveness of the Italian crisis management approach:

(13) “Bloquer le pays ne permet pas d'endiguer l'épidémie, l'Italie l'avait fait et que cela avait été une catastrophe."

(14) "To block the country does not allow to contain the epidemy, Italy has done it and it has been a disaster" (Valeurs actuelles, 2020).

Here the "us" vs. "them" narrative is used in a slightly different way. By adopting the image of "blocking a country," the lockdown measure is framed as overly aggressive and wrongly targeted: it is the country that is put to a halt, not the spread of the virus. The strategy is therefore criticized for being inappropriate ("it does not contain the epidemy") and even detrimental ("it has been a disaster").

Six days later, on 15 March, the count of total infections in France had reached 4,499, of which 838 were new cases, 91 total deaths and 12 new deaths. Moreover, the test positivity rate was 12.770482395436 (ECDC), thus suggesting that there were many more undetected cases. On 13 March, French President Emmanuel Macron ordered all schools and universities to close and gatherings of more than 100 people were also banned; a lockdown was also announced starting on the 17 March.

\section{The Netherlands, 11 March 2020}

As of 11 March, the situation in the Netherlands did not appear to be as worrying as in Italy: a total of 382 cases and 4 deaths had been reported (Roser et al., 2020) and no particularly strict measures were being taken, besides the general recommendations by the National Institute for Public Health and the Environment (RIVM) of not shaking hands, washing hands regularly and staying at home in case of a cold. Crisis management experts such as the director of Crisislab-a research center of Radboud University Nijmegen-Ira Helsloot were asked to comment on the difference between Italy and the Netherlands in crisis management approaches (Nos.nl, 2020).

(15) "De huidige Nederlandse aanpak de enige juiste is. Zwaardere maatregelen zoals het afsluiten van Nederland of enkel Brabant zullen de economie volgens hem alleen maar onherroepelijke schade toebrengen."

(16) "The current Dutch approach is the only correct one. More severe measures such as shutting down the Netherlands or just Brabant will only cause irrevocable damage to the economy."

Hesloot's statement leaves no room for doubt: the "Dutch approach" is not only sound and appropriate, it is the only correct one; the adopted legitimization strategy includes recalling the country's sense of national exceptionalism and using a linear explanation which frames anything else as illegitimate, ineffective, wrong, or worse "stupid":
(17) "Italië bijvoorbeeld, is nu gewoon ongelooflijk dom bezig Ze zorgen door de isolatie dat de eigen samenleving tot stilstand komt. Straks is het coronavirus uitgeroeid, maar ligt de Italiaanse economie op z'n gat. Dan is er geen geld meer voor gezondheidszorg en dat zal het jaren duren voor je erboven komt."

(18) "Italy, for example, is just incredibly stupid now. With this lockdown, they will surely cause a paralysis of their own society. The coronavirus will soon be eradicated, but the Italian economy will be into disrepair. Afterwards, there will be no more money for health care and it will take years before they'll recover."

The much less drastic handling of the pandemic by the Dutch government compared to the Italian strategy is further justified by using the image of a terrifying economic collapse. As in the case of Spanish and French commentators, the minimizing narrative to legitimize the domestic crisis management approach is simple and linear and makes use of explicit and implicit culturalized images that may be familiar to the public: the Dutch are skilled economists, therefore, the Dutch approach is the only possible one. At the same time, however, Hesloot resorts to inappropriate speech: Italians are damaging their own economy, they're being "stupid"; the "us" vs "them" frame is used to explain the "Dutch approach" to the public and in order to seek the necessary support, it justifies a drastic measure to complex problems by dividing the world into an "us" and a "them," in which them are vilified.

The very same strategy of building a simple narrative by means of familiar, culturalized images was adopted by the Dutch Prime Minister Mark Rutte who also resorted to a national stereotype, that of the Dutch as being pragmatic and concrete people:

(19) "Wij zijn een nuchter volkje en zitten niet te wachten op symboolmaatregelen, alleen maar omdat dat dan past bij een gevoel van nu gebeurt er iets."

(20) "We are down-to-earth people and we do not wait for symbolic measures simply to give the feeling that something is being done."

The justifying argument for the Dutch more moderate crisis management strategy is built by using a familiar, highly culturalized image of the Dutch as being sober and pragmatic people in opposition to another cultural stereotype, that of Italians as being superficial, perhaps even frivolous people who therefore care about appearances more than about substance. Within this discourse frame, the Italian lockdown is downplayed as "symbolic" rather than effective, as it only gives "the feeling that something is being done." The repeated use of "we" further stresses the dividing "us" vs. "them" narrative and places emphasis on group identity. This discourse path highlights the differences of the two groups, rejects the values of the Other, and builds confidence and pride in the "us" group.

\section{UK, 13 March 2020}

As of 13 March 2020, Italy counted 21,157 total infections, 3,497 new cases, 1,441 total deaths and 173 new deaths; by the same day, the United Kingdom counted a total of 1,282 
cases, 406 new infections, a total of 9 deaths and 2 new deaths (Roser et al., 2020). On 12 March, after having already prohibited all non-essential activities and services, the Italian government had ordered all Rome's Catholic churches to close due to the pandemic, an unprecedented decision, at least in modern times. On the same day, the UK Chief Medical Officers (CMOs) announced that the coronavirus risk to the UK had been raised from moderate to high (GOV.UK, 2020). With no stricter action taken in comparison with the previous phase, the general recommendations remained to "wash hands more often, for at least 20 seconds, with soap and water," to cough or sneeze into a tissue, and to self-isolate for 7 days if showing certain symptoms, "regardless of whether [people] have traveled to affected areas" (GOV.UK, 2020). Schools were also asked to cancel trips abroad, and people over 70 and those with pre-existing medical conditions were advised to avoid cruises. During a radio show hosted by the UK radio station FUBAR Radio, the British physician and television personality Christian Jessen was asked to comment on the Italian national lockdown. He answered:

(21) “This might be a little bit racist to say this, [and] you'll have to make apologies, but do you not think it's a bit of an excuse? The Italians, any old excuse to, you know, shut down everything and stop work for a bit and have a long siesta."

As done previously by authoritative figures in Spain and the Netherlands, it is again a cultural stereotype that is central to the discourse construction of the crisis as mild. Just like Italians had been framed as "disorganized" in Spain and "stupid" and "frivolous" in the Netherlands, they are now framed as "lazy" and perhaps even "opportunistic" by the British physician. The comment is part of a larger dismissive discourse strategy in which the pandemic is presented as a crisis that has been sensationalized by the media. It is also possible to identify a specific topos, the flu topos which is used to downsize the risk of the novel coronavirus:

(22) "I think it's an epidemic lived out more in the press than in reality. I mean, if you think about flu right, without getting too heavy, flu kills thousands every single year [...] Now I know that's tragic for those involved but it's not exactly huge numbers is it compared to flu, which is thousands. [...] This is like a bad cold really, let's be honest."

The risk of Covid-19 is minimized, this time by drawing comparisons with the flu, framed as much more dangerous ("flu kills thousands" vs. "not exactly huge numbers") than the current pandemic. Such comparisons with the seasonal flu were often made, especially during the first months of the pandemic and not just in the UK. Sometimes they regarded the COVID19 symptoms, frequently referred to as "flu-like symptoms," some other times they referred to the severity of the disease which was "just like the flu" or "like a bad flu," other times yet they concerned the alleged duration of the virus which was "seasonal, just like the flu" or the suggested prevention strategies which were the same "as in any flu season." Although perhaps the most visible public figure of all who repeatedly compared
COVID-19 with the flu was President Donald Trump and his administration (Brooks, 2020), such messages were also spread by traditional media as well as health practitioners - as in the case of UK physician Christian Jessen-, infectious diseases experts ${ }^{7}$ and other authoritative figures. In some cases, the comparison was not explicitly made but nonetheless suggested. Following this linear logic, any alarmism is an irrational overreaction as COVID-19 is "like a bad cold, let's be honest." Within this discourse framework, the risk of COVID-19 is minimized and any alarmism considered as an irrational overreaction. The flu topos immediately associates the novel coronavirus with a known, manageable disease which, in the collective imagination, can be easily overcome. The comparison drawn between an unknown virus and a well-known disease also serves to frame the crisisand particularly the response to it-as scientifically sound and builds the necessary framework to legitimize specific strategies as well as effectively communicate the "reality" of the pandemic to the public. By using the stereotypical image of Italians being lazy ("siesta") and opportunistic ("any old excuse") together with representing the crisis as almost a total media fabrication ("lived out more in the press than in reality"), drastic measures imposed by other countries such as the lockdown in Italy are framed as excessive responses, perhaps even nonsensical if compared to the measures routinely taken by governments to deal with a much more serious disease such as the flu. This stance is confirmed by excerpt 23: when asked whether he agreed with Prime Minister Boris Johnson's decisions to delay closing schools, Jessen said:

(23) "I do agree with him actually. [...] I don't think it's a-it's a real epidemic. Well, it's obviously a real epidemic, but I think we are more worried than we need to be."

\section{DISCUSSION}

The combination of CDA with narrative network analysis allowed for the identification of shared recurring themes and characteristics in the crisis narratives across nations as well as the use of specific discourse strategies across the analyzed categories. In addition to the statements analyzed above, Table 1 below includes further retrieved examples of crisis narratives and themes produced in each country and divided by category.

The findings can be synthetized as follows: attribution of blame and blameworthiness was found to be a common pattern constructed around two main themes: (1) Italy was to blame for having taken inappropriate measures; this narrative was found in all the four countries and (2) Italy was responsible for spreading the virus (Spain). Whereas a comparison with the flu was found to be the most adopted theme used as minimizing strategy in the four countries, the framing of Italian measures as too premature or excessive was found a theme shared by the UK and the Netherlands. All countries adopted culturalized images which were found to be positive if self-referred to the

\footnotetext{
${ }^{7}$ One above all is the example of Dr. Anthony Fauci, director of the American National Institute of Allergy and Infectious Diseases and currently considered among the most official authorities on the COVID-19 response who, on 17 February, described the risk from the novel coronavirus "minuscule" and urged caution in regarding the "influenza outbreak" instead (USA Today, 2020).
} 
TABLE 1 | Statements produced in each category per country.

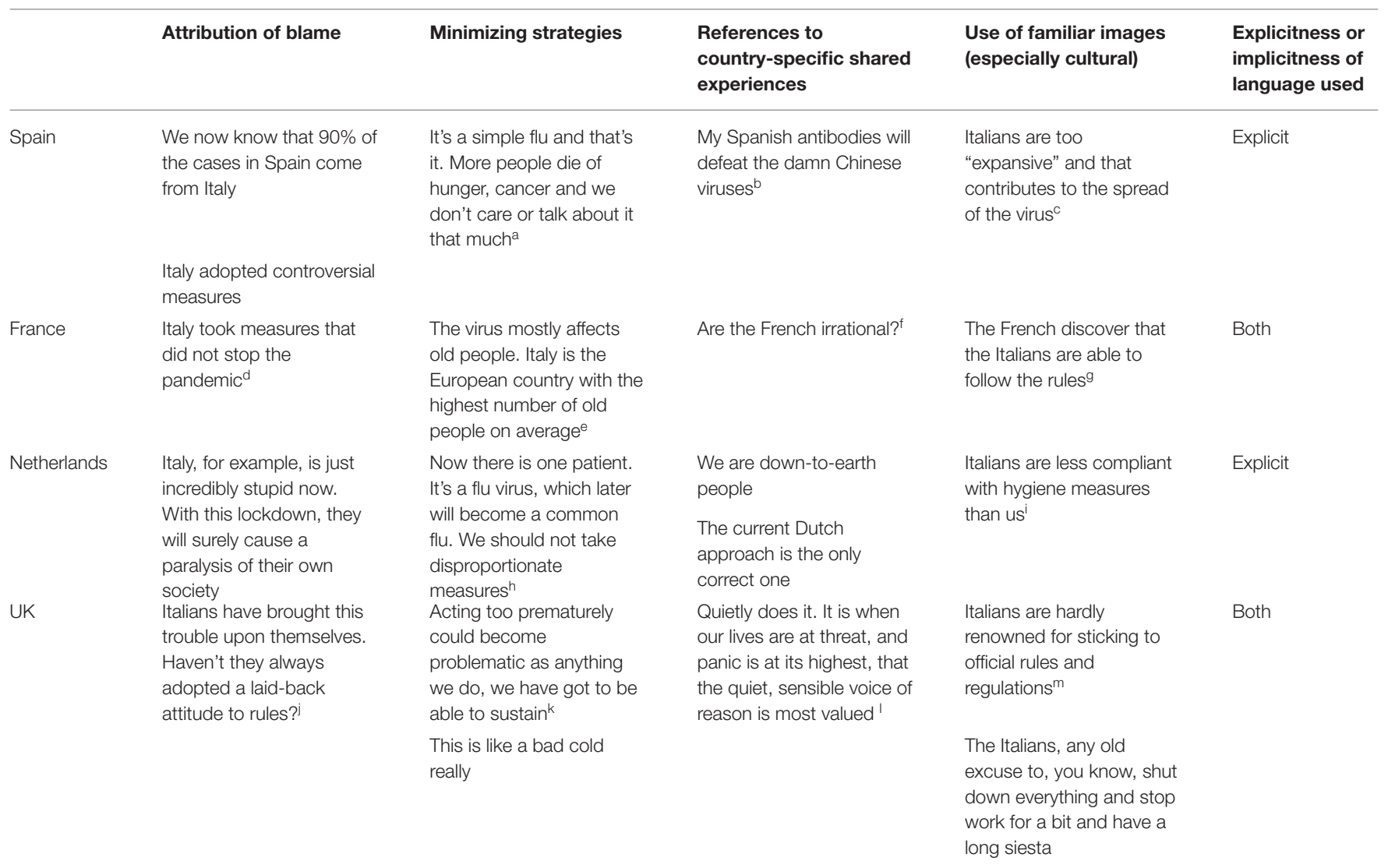

${ }^{a}$ Es una simple gripe y ya esta. Muere mas gente de hambre, de cancer y ni se le da tanta importancia ni se habla lo suficiente (Semana, 11 March 2020).

${ }^{b}$ Mis anticuerpos españoles derrotarán a los malditos virus chinos (El Mundo, 2020).

"Los italianos son demasiado "expansivos" y eso contribuye a la expansión del virus (niusdiario.es, 3 March 2020).

'L'Italie a pris des mesures qui n'ont pas permis d'enrayer l'épidémie (Huffington Post-France, 12 March 2020).

eLe virus touche essentiellement des personnes âgées. L'Italie est le pays avec la moyenne d'âge la plus élevée de l'Union européenne (Atlantico, 11 March 2020).

${ }^{f}$ Les Français sont-ils irrationnels? (Le Figaro, 4 March 2020).

gLes Français découvrent que les Italiens peuvent respecter les règles (Le Figaro, 15 March 2020).

${ }^{h} \mathrm{Nu}$ is er sprake van één patiënt. Het is een griepvirus, dat later een gewone griep zal worden. We moeten geen disproportionele maatregelen nemen (Knack, 1 March 2020).

i'talianen houden zich minder goed aan de hygiënemaatregelen (Nu.nl, 14 March 2020).

jThe Daily Telegraph, 11 March 2020.

kThe Telegraph, 10 March 2020.

'The Daily Telegraph, 14 March 2020.

m The Telegraph, 10 March 2020.

country-specific shared experiences and negative when referred to Italy. For example, the stereotype of Italy as being incapable of following rules was found in the French, Dutch and British excerpts whereas characterizations of Italians as expansive or lazy were found respectively in the Spanish and British excerpts. The use of language was found to be mostly explicit, although instances of implicit language use were also found in the French and British statements. Generally, the adopted discourse strategy constructed a linear, oversimplified "us" vs. "them" narrative. The criticism of Italy as Other-identity was found to be a common communicative device used by the analyzed actors to position themselves and the domestic handling of the crisis as strategically sound. Table 2 shows the relevant statements for each category per country.

The combination of CDA and narrative networks analysis allowed to look specifically at how narratives were produced
TABLE 2 | Themes and strategies across countries.

\begin{tabular}{lllll}
\hline & Spain & France & Netherlands & UK \\
\hline Italy adopted inappropriate measures & Yes & Yes & Yes & Yes \\
It's just like the flu & Yes & Yes & Yes & Yes \\
Us vs. them (self-referred) & Yes & Yes & Yes & Yes \\
Us vs. them & Yes & Yes & Yes & Yes \\
Explicit language & Yes & Yes & Yes & Yes \\
\hline
\end{tabular}

within a network of sequential discourse and factual events and thus also at how they may have impacted on the general understanding of and response to the crisis in the early stages. The identification of the root causes of the crisis as tied to 
the cultural traits of Italians, for example, shaped the crisis as specific to Italy and to its adopted crisis measures and it reassured the population about the concurrent domestic situation. This, in turn, tended to be paired with xenophobic or exceptionalism ideas (e.g., the Netherlands and UK). Similarly, the idea that the virus was merely a flu and not special measures needed to be taken to overcome it framed the crisis as mild. However, if on the one hand this narrative helped to temporarily manage the chaos, on the other, it may have contributed to the subsequent countries' unpreparedness (i.e., subsequent high dead tolls, repeated national lockdowns). Finally, the statements were produced in the space of few days from each other; although it is difficult to establish whether countries were intentionally reproducing each other's narratives, the striking similarities identified in the use of discourse devices and images supports the validity of narrative network analysis as a suitable method for the study of transnational crises and it has therefore much to recommend to communication researchers.

\section{CONCLUSIONS}

Crisis defines a temporary situation which requires immediate intervention and lucid and sound management for order to be restored. This conceptualization frames crisis as a problem-solving challenge which can be resolved through adhoc governmental strategies. In the context of the COVID-19 crisis, domestic pressures and different styles of public health governance resulted in conflicting approaches to the handling of the pandemic across different nations. Especially in the early stages, confronted with an urgent, unprecedented public health crisis, officials found themselves faced with the additional challenge of having to secure public support, especially when their decisions were differing considerably from those of other countries. Such an additional challenge created a discourse void that needed to be filled with credible and compelling narratives to mobilize the general support from the public. This article analyzed the discourse strategies and narratives employed by experts, politicians and other social actors from Spain, France, the Netherlands, and the UK when discussing the Italian crisis management approach in relation to their own response to the COVID-19 outbreak in the early stages of the pandemic. The aim was to identify and compare similarities and differences across these countries in how the crisis was communicated by relevant actors and which discourse strategies were adopted to legitimize their crisis management approaches. Combining CDA with narrative networks analysis, the study also examined how narratives were produced within a network of sequential discourse and factual events and explored how they may have impacted on the general understanding of and response to the crisis.

The study followed events from early February to midMarch and analyzed the adopted communicative devices in statements produced by officially or institutionally entitled public voices from the above-mentioned countries in the first 2 weeks of March. The analysis revealed striking similarities in the way such actors framed the crisis and in the rhetorical devices and images used to describe the internal response in comparison with the Italian response; these can be grouped into three main discourse strategies. First, the narratives attached to nation-specific decisions were highly culturalized, making use of both explicit and implicit cultural stereotypes which were found to be negative when referred to Italy and positive when self-referred. Second, these familiar, stereotypical images were found to be built in contraposition with positive images of the respective countries, thus constructing an "us" vs. "them" narrative. The criticism of Italy as Other-identity was found to be a common communicative device used by the analyzed actors to position themselves and the domestic handling of the crisis as strategically sound whilst creating a sense of membership and solidifying group identity through the use of culturized images. The narratives were found to be always part of a linear, oversimplified narration of the situation in which more complex facts were obscured and the general understanding of the crisis was inevitably shaped as perfectly fitting the domestic approach. Third, although different competing discourse realities were built in each country and different aspects of both the crisis and the measures to tackle it were either emphasized or obfuscated (e.g., the economical aspect in the Netherlands, the health care system in France and Spain), attribution of blame and blameworthiness was found to be a common pattern. This normative stance not only framed Italians as wrongdoers but also as deserving blame (e.g., they don't follow the rules, they're stupid).

Finally, in the Netherlands and in the UK, the legitimization strategies resulted in inappropriate speech, as Italy was respectively referred to as stupid and lazy. These were the latest statements in the narrative network, perhaps indicating that a negative climate of criticism and division was created in the early months of the pandemic, which might have escalated over time and turned into more emotive and culturalized criticisms. Although at this stage it is difficult to assess whether each country's statement was directly responsible for producing a chain reaction and more research is needed in this direction, it is nonetheless worth noticing how the national narratives of crisis seem to have become on the whole increasingly aggressive, nationalistic and less diplomatic.

As it was driven by a close-reading approach, this study included a limited number of sources and examples. Future research could widen the material used for the investigation for instance by extending the timeframe, including more languages and a larger geographical area and pair the investigations with a quantitative network analysis. This could be indeed enriched with a comparison drawn across different times in the pandemic so as to broaden the diversity of perspectives and obtain a richer picture of the COVID-19 crisis communication strategies, in Europe and beyond.

In the context of the COVID-19 pandemic, the globalized proportion of the crisis forced governments and public health officials to take immediate action but more importantly, to present such actions to the public as the best possible strategies. With the exception of moderate differences between the analyzed countries, narrative networks analysis showed that such strategies were communicated through the lens of each country's sense 
of exceptionalism and superiority, built in opposition with the denigration of Italy as the Other-identity. Ultimately, understanding the linguistic devices used for narrating a crisis is vitally important as a foundation for understanding the response to the crisis itself. Despite the limited sample analyzed here, the findings of this study have already important implications. The analysis highlighted patterns of discourse strategies across the four countries' crisis narratives which arguably shaped the understanding of the crisis as mild; they did so by criticizing the Italian strategy, by comparing coronavirus to influenza, and by resorting to xenophobic or exceptionalism ideas. As discourse shapes and it is shaped by public events, the way crises are narrated has immediate consequences for news framing, public understanding, and policy and therefore the results of this study crucially point to the wider issue of using appropriate linguistic devices when communicating a crisis. For example, in the language of crisis, rather than employing inappropriate frames which perpetuate stereotyped cultural images and create a polarized climate of mistrust and division, a more critical, self-reflective, and transparent approach

\section{REFERENCES}

Amante, A., and Anzolin, E. (2020). First Italian dies of coronavirus as outbreak flares in north. Reuters. Available online at: https://www.reuters.com/article/uschina-health-italy-idUSKBN20F0UI (accessed February 21, 2020).

Anthony, L. (2019). AntConc 3.5.8. Waseda University. Available online at: http:// www.antlab.sci.waseda.ac.jp/

Arceneaux, K., and Johnson, M. (2013). Changing Minds or Changing Channels? Partisan News in an Age of Choice. Chicago, IL: The University of Chicago Press.

Atkinson, M. L. (2017). Combative Politics: The Media and Public Perceptions of Lawmaking. Chicago, IL: The University of Chicago Press.

Bajaj, G., Khandelwal, S., and Budhwar, P. (2021). COVID-19 pandemic and the impact of cross-cultural differences on crisis management: a conceptual model of transcultural crisis management. Int. J. Cross Cult. Manag. 21, 569-601. doi: $10.1177 / 14705958211060189$

Baker, P., Gabrielatos, C., and McEnery, T. (2013). Discourse Analysis and Media Attitudes: The Representation of Islam in the British Press. Cambridge: Cambridge University Press.

BBC News (2020). Coronavirus: Italy Extends Emergency Measures Nationwide. BBC News. Available online at: https://www.bbc.com/news/world-europe51810673 (accessed March 10, 2020).

Bearman, P. S., and Stovel, K. (2000). Becoming a Nazi: a model for narrative networks. Poetics 27, 69-90. doi: 10.1016/S0304-422X(99)00 $022-4$

Berliner Morgenpost (2020). Coronavirus: Interaktive Karte zeigt aktuelle Zahl der Corona-Infektionen in Deutschland, Europa und weltweit. Berliner Morgenpost. Available online at: https://interaktiv.morgenpost.de/coronavirus-karte-infektionen-deutschland-weltweit/ (accessed September 29, 2020).

BFM TV (2020). Olivier Véran sur le confinement: "L'Italie fait face à une très grande détresse de son système hospitalier." Available online at: https://www. bfmtv.com/politique/olivier-veran-sur-le-confinement-l-italie-fait-face-aune-tres-grande-detresse-de-son-systeme-hospitalier_VN-202003090224. html (accessed March 9, 2020).

Boydstun, A. E. (2013). Making the News: Politics, the Media, and Agenda Setting. Chicago, IL: The University of Chicago Press.

Brooks, B. (2020). Like the flu? Trump's coronavirus messaging confuses public, pandemic researchers say. Reuters. Available online at: https://www.reuters. com/article/us-health-coronavirus-mixed-messages-idUSKBN2102GY (accessed March 14 2020).

Bryant, J., Zillmann, D., Bryant, J., and Oliver, M. B. (Eds.). (2002). Media Effects: Advances in Theory and Research (2nd ed.). London: Routledge. should be adopted which could contribute to more appropriate crisis responses.

\section{DATA AVAILABILITY STATEMENT}

Publicly available datasets were analyzed in this study. This data can be found here: https://www.ecdc.europa.eu/en/publicationsdata/download-todays-data-geographic-distribution-covid-19cases-worldwide.

\section{AUTHOR CONTRIBUTIONS}

The author confirms being the sole contributor of this work and has approved it for publication.

\section{FUNDING}

This study was supported by the FNR - Luxembourg National Research Fund under Grant No. 13307816.

Coombs, W. T. (2007). Protecting organization reputations during a crisis: the development and application of situational crisis communication theory. Corp. Reput. Rev. 10, 163-176. doi: 10.1057/palgrave.crr.1550049

Corriere della Sera (2020). Coronavirus, primi due casi in Italia: Sono due turisti cinesi. Corriere della Sera. Available online at: https://www.corriere.it/ cronache/20_gennaio_30/coronavirus-italia-corona-9d6dc436-4343-11eabdc8-faf1f56f19b7.shtml (accessed January 30 2020)

Douglas, K. M. (2021). COVID-19 conspiracy theories. Group Process. Intergroup Relat. 24, 270-275. doi: 10.1177/1368430220982068

Drosten, C., Günther, S., Preiser, W., van der Werf, S., Brodt, H.-R., Becker, S., et al. (2003). Identification of a novel coronavirus in patients with severe acute respiratory syndrome. New Engl. J. Med. 348, 1967-1976. doi: 10.1056/NEJMoa030747

Edwards, D. (1997). Discourse and Cognition (pp. vii, 356). Thousand OAKS, CA: Sage Publications, Inc.

El Mundo (2020). Críticas a Italia por la gestión de la epidemia de coronavirus. El Mundo. Available online at: https://www.elmundo.es/ciencia-y-salud/salud/ 2020/03/02/5e5c0bb0fc6c838e278b4683.html (accessed March 2 2020)

Entman, R. M. (2003). Projections of Power: Framing News, Public Opinion, and U.S. Foreign Policy (Studies in communication, media, and public opinion). Chicago, IL: University of Chicago Press.

Fairclough, N., and Wodak, R. (1997). "Critical discourse analysis," in Discourse Studies: A Multidisciplinary Introduction (Vol. 2), ed T. van Dijk (Thousand Oaks, CA: SAGE).

Fidler, D. (2004). SARS, Governance and the Globalization of Disease. London: Palgrave Macmillan

Gimenez, J. (2010). Narrative Analysis in Linguistic Research, ed. L. Litosseliti. Continuum, 198-215. Available online at: https://westminsterresearch. westminster.ac.uk/item/9650z/narrative-analysis-in-linguistic-research (accessed February 07, 2022).

GOV.UK (2020). COVID-19: Government Announces Moving Out of Contain Phase and Into Delay. GOV.UK. Available online at: https://www.gov. uk/government/news/covid-19-government-announces-moving-out-ofcontain-phase-and-into-delay (accessed March 12, 2020).

Guzmán, P. J. (2020). Fernando Simón: «El 90\% de los casos de coronavirus en España proceden de Italia $\gg$. Newtral. Available online at: https://www.newtral. es/fernando-simon-el-90- de-los-casos-de-coronavirus-en-espana-procedende-italia/20200302/ (accessed March 2, 2020).

Jäger, S. (2001). "Discourse and knowledge: theoretical and methodological aspects of a critical discourse and dispositive analysis," in Methods of critical discourse analysis, eds R. Wodak and M. Meyer (Thousand Oaks, CA: SAGE), 32-62. 
Ksiazek, T. G., Erdman, D., Goldsmith, C. S., Zaki, S. R., Peret, T., Emery, S., et al. (2003). A novel coronavirus associated with severe acute respiratory syndrome. New Engl. J. Med. 348, 1953-1966. doi: 10.1056/NEJMoa030781

LeDuc, J. W., and Barry, M. A. (2004). SARS, the first pandemic of the 21st Century1. Emerg. Infect. Dis. 10, e26. doi: 10.3201/eid1011.040797_02

Nos.nl (2020). Crisis-Experts: Onze Corona-Aanpak Is Goed, Communicatie Kan Beter. Available online at: https://nos.nl/1/2326736 (accessed March 11, 2020)

Patrona, M. (2006). Conversationalization and media empowerment in Greek television discussion programs. Discourse Soc. 17, 5-27. doi: $10.1177 / 0957926506058062$

Patrona, M. (2012). Journalists on the news: the structured panel discussion as a form of broadcast talk. Discourse Soc. 23, 145-162. doi: 10.1177/0957926511431505

Patrona, M. (2018). Crisis and the Media. In Dapsac.76. John Benjamins Publishing Company. Available online at: https://benjamins.com/catalog/dapsac.76

Potter, J., Edwards, D., and Wetherell, M. (2016). A model of discourse in action: Am. Behav. Sci. 36, 383-401. doi: 10.1177/0002764293036003008

Potter, J., and Wetherell, M. (1987). Discourse and Social Psychology: Beyond Attitudes and Behaviour. Thousand Oaks, CA: Sage Publications, Inc, 216

Pummerer, L., Böhm, R., Lilleholt, L., Winter, K., Zettler, I., and Sassenberg, K. (2022). Conspiracy theories and their societal effects during the COVID-19 pandemic. Social Psychol. Personal. Sci. 13, 49-59. doi: $10.1177 / 19485506211000217$

Ratto Trabucco, F. (2020). Riflessioni sui D.P.C.M. marzolini "di salute pubblica" sull'emergenza Coronavirus con limitazioni draconiane ai diritti costituzionali a mezzo atto amministrativo. lexitalia.it. Giuriconsult s.r.l. editor, Palermo.

Reuters, L. F. avec A. et. (2020). Coronavirus: Cinq nouveaux cas en France annonce Buzyn, deux écoles fermées en Haute-Savoie. Le Figaro.fr. Available online at: https://www.lefigaro.fr/sciences/coronavirus-5-nouveaux-cas-enfrance-20200208 (accessed February 8, 2020).

Reynolds, B., and and, W., Seeger, M. (2005). Crisis and emergency risk communication as an integrative model. J. Health Commun. 10, 43-55. doi: 10.1080/10810730590904571

Roser, M., Ritchie, H., Ortiz-Ospina, E., and Hasell, J. (2020). Coronavirus Pandemic (COVID-19). Our World in Data. Available online at: https:// ourworldindata.org/coronavirus (accessed February 07, 2022).

Safi, M., Giuffrida, A., and Farrer, M. (2020). Coronavirus: Italy Bans Any Movement Inside Country As Toll Nears 5,500. The Guardian. Available online at: https://www.theguardian.com/world/2020/mar/22/italian-pm-warns- ofworst-crisis- since-ww2-as-coronavirus-deaths-leap-by-almost-800 (accessed March 22, 2020).

Saunders, B., Sim, J., Kingstone, T., Baker, S., Waterfield, J., Bartlam, B., et al. (2018). Saturation in qualitative research: exploring its conceptualization and operationalization. Qual. Quant. 52, 1893-1907. doi: 10.1007/s11135-017-0574-8

Seeger, M., and Sellnow, T. L. (2016). Narratives of Crisis: Telling Stories of Ruin and Renewal. Stanford: Stanford University Press.

Stein, R. A., Ometa, O., Pachtman Shetty, S., Katz, A., Popitiu, M. I., and Brotherton, R. (2021). Conspiracy theories in the era of COVID-19: a tale of two pandemics. Int. J. Clin. Pract. 75:e13778. doi: 10.1111/ijcp.13778

Stokes, J. (2021). How to do Media and Cultural Studies. London: Sage.

United Nations (2020). UN Tackles 'Infodemic' of Misinformation and Cybercrime in COVID-19 Crisis. United Nations; United Nations. Available online at: https://www.un.org/en/un-coronavirus-communications-team/un-tackling$\% \mathrm{E} 2 \% 80 \% 98$ infodemic\%E2\%80\%99-misinformation-and-cybercrime-covid19 (accessed March, 28, 2020)
USA Today (2020). Top Disease Official: Risk of Coronavirus in USA is "Minuscule"; Skip Mask and Wash Hands. USA TODAY. Available online at: https://www. usatoday.com/story/news/health/2020/02/17/nih-disease-official-anthonyfauci-risk-of-coronavirus-in-u-s-is-minuscule-skip-mask-and-wash-hands/ 4787209002/ (accessed February 17, 2020).

Valeurs actuelles (2020). Coronavirus: Après avoir critiqué l'Italie, la France s'en inspire. Valeurs actuelles. Available online at: https://www.valeursactuelles. $\mathrm{com} /$ politique/coronavirus-apres-avoir-critique-litalie-la-france-sen-inspire117319 (accessed March 20, 2020).

van Dijk, T. A. (ed.). (1985). Discourse and Communication: New Approaches to the Analysis of Mass Media Discourse and Communication. Berlin: De Gruyter.

WHO (2020a). Statement on the Second Meeting of the International Health Regulations (2005). Emergency Committee Regarding the Outbreak of Novel Coronavirus (2019-nCoV). Available online at: https://www.who. $\mathrm{int} /$ news-room/detail/30-01-2020-statement-on-the-second-meeting-of-theinternational-health-regulations-(2005)-emergency-committee-regardingthe-outbreak-of-novel-coronavirus-(2019-ncov) (accessed January 30, 2020).

WHO (2020b). WHO Director-General's Opening Remarks at the Media Briefing on COVID-19-11 March 2020. Available online at: https://www.who.int/ $\mathrm{dg} /$ speeches/detail/who-director-general-s-opening-remarks-at-the-mediabriefing-on-covid-19-11-march-2020 (accessed March 11, 2020)

WHO (2020c). Public Health Criteria to Adjust Public Health and Social Measures in the Context of COVID-19. Available online at: https://www. who.int/publications-detail-redirect/public-health-criteria-to-adjust-publichealth-and-social-measures-in-the-context-of-covid-19 (accessed May $12,2020)$

WHO|Novel Coronavirus-China (2020). WHO; World Health Organization. Available online at: http://www.who.int/csr/don/12-january-2020-novelcoronavirus-china/en/ (accessed January 12, 2020).

Wodak, R., and Angouri, J. (2014). From grexit to grecovery: euro/crisis discourses. Discourse Soc. 25, 417-423. doi: 10.1177/095792651453 6967

Wodak, R., and Meyer, M. (2001). Methods of Critical Discourse Analysis. Thousand Oaks: SAGE.

Yle Uutiset (2020). Finland's First Coronavirus Case Confirmed in Lapland. Yle Uutiset. Available online at: https://yle.fi/uutiset/osasto/news/finlands first_coronavirus_case_confirmed_in_lapland/11182855 (accessed January 29, 2020).

Conflict of Interest: The author declares that the research was conducted in the absence of any commercial or financial relationships that could be construed as a potential conflict of interest.

Publisher's Note: All claims expressed in this article are solely those of the authors and do not necessarily represent those of their affiliated organizations, or those of the publisher, the editors and the reviewers. Any product that may be evaluated in this article, or claim that may be made by its manufacturer, is not guaranteed or endorsed by the publisher.

Copyright (c) 2022 Viola. This is an open-access article distributed under the terms of the Creative Commons Attribution License (CC BY). The use, distribution or reproduction in other forums is permitted, provided the original author(s) and the copyright owner(s) are credited and that the original publication in this journal is cited, in accordance with accepted academic practice. No use, distribution or reproduction is permitted which does not comply with these terms. 